\title{
Effect of affordable disinfectant solutions on Candida albicans adhered to acrylic resin for dental prosthesis
}

\author{
Efeito de soluções desinfetantes acessiveis sobre Candida albicans aderida à resina acrílica usada em \\ prótese dentária
}

Lina Naomi HASHIZUME'

Murilo Fernandes HOSCHARUK ${ }^{1}$

Maurício José Santos MOREIRA ${ }^{1}$

\section{ABSTRACT}

\section{Objective}

To evaluate the effect of different low-cost disinfectant solutions on Candida albicans (C. albicans) adhered to acrylic resin used in dental prosthesis.

\section{Methods}

Sixty acrylic resin specimens were divided into four experimental groups according to the disinfecting agent tested (2\% chlorhexidine, $1 \%$ sodium hypochlorite, vinegar and $10 \mathrm{v}$ hydrogen peroxide) and two control groups. Fifty specimens were incubated with C. albicans and after immersed in the disinfecting solutions or saline (negative control). Specimens without contamination constituted the positive control group. After disinfection procedures, all specimens were immersed in a culture medium and incubated for 24 hours at $37^{\circ} \mathrm{C}$. Culture media turbidity was evaluated.

\section{Results}

The disinfectants $2 \%$ chlorhexidine and $1 \%$ sodium hypochlorite performed a maximal reduction of C. albicans. Vinegar showed intermediate antifungal effect and 10v hydrogen peroxide showed a lower effect.

\section{Conclusions}

Among the disinfecting solutions tested in the present study, 2\% chlorhexidine and 1\% sodium hypochlorite are the most effective in the reduction of C. albicans adhered to acrylic resin. However, vinegar may represent a viable and low-cost alternative to prosthesis disinfection.

Indexing terms: Candida albicans. Dental prosthesis. Disinfection.

\section{RESUMO}

\section{Objetivo}

Avaliar o efeito de diferentes soluções desinfetantes de baixo custo sobre Candida albicans (C. albicans) aderida a resina acrílica usada em prótese dentária.

\section{Métodos}

Sessenta espécimes de resina acrílica foram divididos em 4 grupos experimentais de acordo com o agente desinfetante testado (clorexidina a $2 \%$, hipoclorito de sódio a $1 \%$, vinagre e peróxido de hidrogênio 10v) e 2 grupos controle. Cinquenta espécimes foram incubados com C. albicans e após imersos nas soluções desinfetantes ou salina (controle negativo). Espécimes sem contaminação constituíram o grupo controle positivo. Após os procedimentos de desinfecção, todos os espécimes foram imersos em um meio de cultura e incubados por 24 horas a $37^{\circ} \mathrm{C}$. A turbidez do meio de cultura foi avaliada.

\section{Resultados}

Os desinfetantes clorexidina a $2 \%$ e hipoclorito de sódio a $1 \%$ apresentaram a redução máxima de C. albicans. O vinagre mostrou efeito antifúngico intermediário e o peróxido de hidrogênio $10 \mathrm{v}$ apresentou o menor efeito dentre eles.

\section{Conclusões}

Baseado nos resultados do presente estudo, clorexidina a $2 \%$ e hipoclorito de sódio a $1 \%$ são mais efetivas em reduzir C. albicans aderida à resina acrílica. Entretanto, o vinagre pode representar uma alternativa viável e de baixo custo para a desinfecção de próteses.

Termos de indexação: Candida albicans. Prótese dentária. Desinfecção.

\footnotetext{
${ }^{1}$ Universidade Federal do Rio Grande do Sul, Faculdade de Odontologia, Departamento de Odontologia Preventiva e Social. Rua Ramiro Barcelos, 2492, 90035-003, Porto Alegre, RS, Brasil. Correspondência para / Correspondence to: LN HASHIZUME. E-mail: <lhashizume@yahoo.com>.
} 


\section{INTRODUCTION}

Denture-induced stomatitis is reported to be an inflammatory reaction of the denture-bearing mucosa, being characterized by different degrees of erythema and affects many complete upper denture wearers ${ }^{1-3}$. Despite the multifactorial etiology of this disease, Candida albicans is still reported as the primary etiologic agent ${ }^{4}$. The surface of dental prosthesis containing microporosities which can become a reservoir for microorganisms and provide an ideal environment for growth of Candida albicans, which easily adheres to this acrylic surface ${ }^{5-6}$.

An effective method to clean dental prosthesis surface and control microbial growth is the periodic mechanical disruption of the biofilm formed on the denture surfaces. However some prosthesis wearers as elderly patients and individuals with limited motor capacity have difficulty to maintain their prosthesis clean only with mechanical biofilm control-9. For these patients is recommended the use of mechanical associated with chemical cleaning for reducing microbial biofilm accumulation on dental prosthesis ${ }^{10-11}$.

Chemical cleaning consists prosthesis immersion in solutions containing chemical agents ${ }^{12}$. Though the complete immersion of prosthesis in solutions with chemical agents can have adverse effects such as increased roughness and reduction in hardness of the denture acrylic surface ${ }^{13}$. Furthermore acrylic resin prosthesis treated by chemical solutions can absorb these liquids because resins have the capacity of sorption of liquids ${ }^{14}$. The chemical agent must be safe to be used in disinfection since it might be released in the oral cavity when prosthesis are back into use ${ }^{15}$.

The safety of the use of solutions as chlorhexidine, sodium hypochlorite, vinegar and hydrogen peroxide is reported in the literature ${ }^{16-24}$. They presented biocompatibility and low cytotoxicity when used in low concentrations being safe for denture chemical disinfection. These disinfecting solutions are affordable to the population, easily available in the market and present possible antifungal effect against Candida albicans.

Despite the advantages and market availability of chemical agent's solutions for disinfection of dental prosthesis, less than $60 \%$ of the denture wearers use anyone due to the cost of the product ${ }^{25}$.

Therefore, for a denture disinfectant to be affordable to most of patients it should also have a low cost. The aim of this study was to evaluate the effect of four different affordable disinfectant solutions on Candida albicans adhered to acrylic resin used in base of dental prosthesis. The null hypothesis tested in this study was that no difference exists in antifungal activity of the different tested products.

\section{METHODS}

Sixty standardized specimens $(25 \times 25 \times 3 \mathrm{~mm})$ were fabricated with a microwaved-polymerized acrylic resin (Onda Cryl; Artigos Odontológicos Clássicos, São Paulo, Brazil) according to manufacturer recommendations. The sample size was determined based on previous studies testing chemical agents for the disinfection of dental prosthesis using similar protocol ${ }^{26}$. No polishing procedures were done in order to simulate the inner surface of a complete denture.

All the specimens were immersed previously in distilled water to promote maximum sorption of water and to prevent the occurrence of distortion and release of residual monomer after polymerization. After the specimens were submitted to a sterilization process with hydrogen peroxide plasma.

Pure cultures of Candida albicans ATCC 18804 were plated on Sabouraud with chloramphenicol agar plates (Oxoid; Basingstoke, UK) and incubated at $37^{\circ} \mathrm{C}$ for 24 hours. After this period, the colonies were inoculated in tubes containing $5 \mathrm{~mL}$ of Brain Heart Infusion (Oxoid; Basingstoke, UK). The suspension containing Candida albicans's cells was adjusted using a spectrophotometer at $800 \mathrm{~nm}(\mathrm{OD} 800)$ and transmittance $90 \mathrm{~T}$ (equivalent to $0.5 \mathrm{McF}$ arland scale $\left.=1.5 \times 10^{8} \mathrm{CFU}\right)^{27}$.

The specimens were incubated at $37^{\circ} \mathrm{C}$ for 24 hours in tubes containing the Candida albicans standardized suspension to promote the contamination of specimens, except the group served as positive control. After the specimens were washed with sterile saline and randomly divided in 5 groups according the disinfecting solution or negative control group (10 specimens in each group). The tested solutions were: $2 \%$ chlorhexidine solution (Pharmaplus, Porto Alegre, Brazil); $1 \%$ sodium hypochlorite solution (Iodontec, Porto Alegre, Brazil); $100 \%$ vinegar $(4.5 \%$ acetic acid, Villa Lima, San José, Uruguay); $10 \vee$ hydrogen peroxide (Drogaria Paysandú, Shangrilá, Uruguay); contaminated specimens, exposed to saline solution (negative control) and specimens without contamination, exposed to saline solution (positive control). All specimens were immersed for 10 minutes in the different solutions. After immersion, the specimens were washed with sterile saline solution and transferred to individual tubes containing $5 \mathrm{~mL}$ of Brain Heart Infusion 
and incubated at $37^{\circ} \mathrm{C}$ for 24 hours. The fungal growth was evaluated by observing the turbidity of the culture medium with the aid of a spectrophotometer at $530 \mathrm{~nm}$.

Aliquots of the medium of each tube were collected and inoculated on Sabouraud with chloramphenicol agar plates to check the growth of Candida albicans. The colony morphology on agar plates and the microscopic morphology of the cells were verified in order to confirm the purity of the positive cultures.

The results were statistically analyzed using Social Package for the Social Science 14.0 software (SPSS Inc., Chicago, USA) for Windows using one-way ANOVA followed by Tukey test, with significance level of $5 \%$.

\section{RESULTS}

Figure 1 shows the transmittance values of each disinfecting solution or controls. The means ( \pm standard deviation) of transmittance values for each treatment were: $2 \%$ chlorhexidine $=97.44 \pm 0.45 ; 1 \%$ sodium hypochlorite $=97.53 \pm 0.27$; vinegar $=93.0 \pm 1.49 ; 10$ $\vee$ hydrogen peroxide $=76.24 \pm 2.69$; negative control $=$ $72.44 \pm 1.65$ and positive control $=97.81 \pm 0.84$.

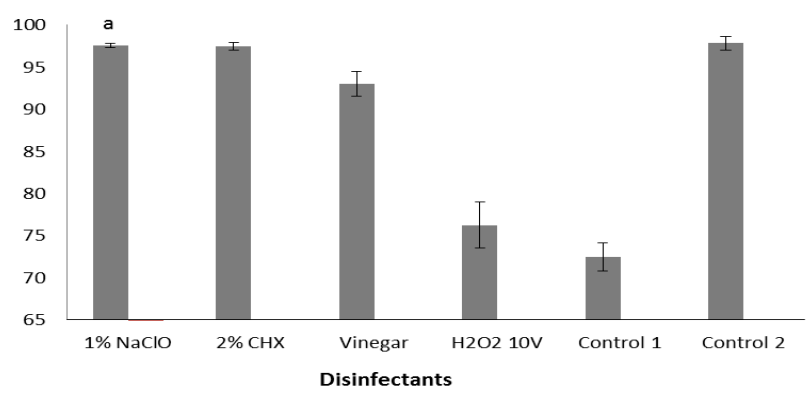

Figure 1. Means of transmittance values for the disinfectants tested and controls $(n=10)$. Different letters mean statistically significant difference (ANOVA Tukey test, $p<0.05) .1 \% \mathrm{NaClO}: 1 \%$ sodium hypochlorite solution, $2 \%$ CHX: $2 \%$ chlorhexidine solution, vinegar: $100 \%$ vinegar, $\mathrm{H}_{2} \mathrm{O}_{2}$ 10v: $10 \mathrm{v}$ hydrogen peroxide, negative control: contaminated specimens exposed to saline solution, positive control: specimens without contamination exposed to saline solution.

All the disinfecting solutions tested in this study showed reduction of Candida albicans in culture media comparing to negative control $(p<0.05)$. The groups $2 \%$ chlorhexidine, $1 \%$ sodium hypochlorite and positive control showed higher transmittance values. There was no significant difference between groups treated with $2 \%$ chlorhexidine and $1 \%$ sodium hypochlorite $(p>0.05)$.
Both groups were similar to the positive control that had specimens without contamination.

The groups vinegar, $10 v$ hydrogen peroxide and negative control showed statistical differences between themselves and in relation to groups $2 \%$ chlorhexidine, $1 \%$ sodium hypochlorite and positive control $(p<0.05)$.

\section{DISCUSSION}

The search for new methods to control the formation of Candida albicans biofilm in the process of disinfection of acrylic resin used in base of dental prosthesis must verify the antifungal efficacy. However, to a denture disinfectant be affordable to most of patients the cost of this product must also be considered, based on socio economic status of each patient.

The present study tested the antifungal efficacy of 4 disinfectant solutions ( $2 \%$ chlorhexidine, $1 \%$ sodium hypochlorite, vinegar and $10 \mathrm{v}$ hydrogen peroxide) against Candida albicans biofilm adhered to the surface of microwave-polymerized acrylic resin. The null hypothesis of this study was rejected because the products tested showed different antifungal activities.

In the present study $2 \%$ chlorhexidine and $1 \%$ sodium hypochlorite performed a maximal inhibition. The effectiveness of chlorhexidine in the reduction of Candida albicans adhered to the denture resin surface when used in the concentrations of $2 \%$ or $4 \%$ is reported in the literature. Chlorhexidine presents many advantages as antimicrobial properties in low concentration, high substantivity and reduce biofilm formation. However it also presents some side effects which mean that it is not recommended for daily use in the prosthesis disinfection ${ }^{10}$.

In the present study the $1 \%$ sodium hypochlorite was able to reduce Candida albicans from the resin surface, and this result was similar to $2 \%$ chlorhexidine. Sodium hypochlorite used in concentrations as $0.5 \%, 1 \%$ and $5.25 \%$ presents satisfactory results in removal of Candida albicans ${ }^{10}$. However, sodium hypochlorite can damage acrylic resin denture and leave unpleasant residual taste and its use is also not recommended frequently.

The hydrogen peroxide acts in chemical and mechanical way because during its degradation it promotes oxidation and oxygen release damaging the microbial cells and interfering with cell division ${ }^{17}$. Montagner et al. showed that 10 v hydrogen peroxide solution was efficient against Candida albicans when used during 30 minutes $^{27}$. In the present study, 10 v hydrogen peroxide showed the lowest antifungal effect against Candida albicans compared to other tested disinfectants. A possible 
explanation for this difference is the immersion period used in the present study that was 10 minutes, lower than that used by cited authors. This immersion period of 10 minutes established for all disinfectants tested in this study simulate a period of time that the wearers use to perform disinfection of their prosthesis during the daily hygiene.

Vinegar is an acetic acid solution which presents low cost and low toxicity and it could be an alternative to conventional denture disinfectants ${ }^{20}$. Therefore the inclusion of this substance in the present study was based on its easy availability and affordable to the population and some studies have shown its antimicrobial potential ${ }^{20,24}$. In the present study, vinegar showed an antifungal effect lower than those obtained with $2 \%$ chlorhexidine and $1 \%$ sodium hypochlorite. However, its results were even better than $10 \mathrm{v}$ hydrogen peroxide, demonstrating its substantial antifungal effect against Candida albicans. Although the vinegar solution was not able to eliminate Candida albicans completely its antifungal effect could be greater if the period of immersion of the denture was longer. However further studies are necessary to verified this possibility.

The denture cleaning using solution with chemical agents periodically can bring many side effects. Therefore it requires a need to research for alternative disinfecting solutions to replace conventional chemical disinfectants. The choice of disinfectants tested in this study was based on the cost, easy availability of the product and its possible

\section{REFERENCES}

1. Webb BC, Thomas CJ, Willcox MD, Harty DW, Knox KW. Candida associated denture stomatitis. A etiology and management: a review. Part 2. Oral diseases caused by Candida species. Aust Dent J. 1998;43(3):160-6. doi: 10.1111/j.1834-7819.1998. tb00157.x

2. Arendorf TM, Walker DM. Oral candidal population in health and disease. Br Dent J. 1979;147(10):267-71.

3. Cumming CG, Wight $C$, Blackwell CL, Wray D. Denture stomatitis in the elderly. Oral Microbiol Immunol. 1990;5(2):82-5.

4. Nikawa H, Yamamoto T, Hamada T, Sadamori S, Agrawal S. Cleansing efficacy of commercial denture cleansers: ability to reduce Candida albicans biofilm activity. Int J Prosthodont. 1995;8(6):527-34.

5. Coulthwaite L, Verran J. Potential pathogenic aspects of denture plaque. Br J Biomed Sci. 2007;64(4):180-9.

6. Baysan A, Whiley R, Wright PS. Use of microwave energy to disinfect a long-term soft lining material contaminated with Candida albicans or Staphylococcus aureus. J Prosthet Dent. 1998;79(4):454-8. doi:10.1016/S0022-3913(98)70161-1 antifungal effect against Candida albicans. The results of the present study showed that vinegar may be a low-cost and viable alternative to conventional chemical agents.

Since many disinfecting agents for prosthesis are commercially available, it is important to know about its antimicrobial efficacy. However, the cost of each disinfecting solution must be considered, based on socioeconomic status of the patient.

\section{CONCLUSION}

Within the limitations of this in vitro study, it can be concluded that among the disinfecting solutions tested, $2 \%$ chlorhexidine and $1 \%$ sodium hypochlorite were the most effective in the reduction of Candida albicans adhered to acrylic resin for dental prosthesis. Howevwe, vinegar may represent a low-cost and viable alternative to prosthesis disinfection.

\section{Collaborators}

LN HASHIZUME was responsible for designing the research project, planning stages, analysis and interpretation of results and writing of the manuscript. MF HOSCHARUK was responsible for implementing the experimental phase and writing of the article. MJS MOREIRA was responsible for writing of the manuscript.

7. Kulak-Ozkan Y, Kazazoglu E, Arikan A. Oral hygiene habits, denture cleanliness, presence of yeasts and stomatitis in elderly people. J Oral Rehabil. 2002;29(3):300-4. doi: 10.1046/j.13652842.2002.00816.x

8. Odman PA. The effectiveness of an enzyme-containing denture cleanser. Quintessence Int. 1992;23(3):187-90.

9. Budtz-Jørgensen E. Materials and methods for cleaning dentures. J Prosthet Dent. 1979;42(6):619-23.

10. Nikawa $H$, Hamada $T$, Yamashiro $H$, Kumagai $H$. A review of in vitro and in vivo methods to evaluate the efficacy of denture cleansers. Int J Prosthodont. 1999;12(2):153-9.

11. Barnabé $W$, Mendonça-Neto T, Pimenta FC, Pegoraro LF, Scolaro JM. Efficacy of sodium hypoclorite and coconut soap used as disinfecting agents in the reduction of denture stomatitis, Streptococcus mutans and Candida albicans. J Oral Rehabil. 2004;31(5):453-9. doi: 10.1111/j.13652842.2004.01254.x

12. Budtz-Jörgensen E. Clinical aspects of Candida infection in denture wearers. J Am Dent Assoc. 1978;96(3):474-9.

13. Braun KO, Mello JA, Rached RN, Del Bel Cury AA. Surface texture and some properties of acrylic resins submitted to chemical 
polishing. J Oral Rehabil. 2003;30(1):91-8. doi: 10.1046/j.13652842.2003.00997.x

14. Ellepola AN, Samaranayake LP. Adjunctive use of chlorhexidine in oral candidoses: a review. Oral Dis. 2001;7(1):11-7. doi: 10.1034/j.1601-0825.2001.70103.x

15. Jenkins $S$, Addy $M$, Wade $W$. The mechanism of action of chlorhexidine: a study of plaque growth on enamel inserts in vivo. J Clin Periodontol. 1988;15(7):415-24. doi: 10.1111/j.1600051X.1988.tb01595.x

16. Kulak Y, Arikan A, Delibalta N. Comparison of three different treatment methods for generalized denture stomatitis. J Prosthet Dent. 1994;72(3):283-8. doi:10.1016/0022-3913(94)90341-7

17. Pavarina AC, Pizzolitto AC, Machado AL, Vergani CE, Giampaolo ET. An infection control protocol: effectiveness of immersion solutions to reduce the microbial growth on dental prostheses. J Oral Rehabil. 2003;30(5):532-6. doi: 10.1046/j.13652842.2003.01093.x

18. lacopino AM, Wathen WF. Oral candidal infection and denture stomatitis: a comprehensive review. J Am Dent Assoc. 1992;123(1):46-51.

19. Ferretti GA, Raybould TP, Brown AT, Macdonald JS, Greenwood M Maruyama Y, et al. Chlorhexidine prophylaxis for chemotherapyand radiotherapy-induced stomatitis: a randomized doubleblind trial. Oral Surg Oral Med Oral Pathol. 1990;69(3):331-8.

20. Chau VB, Saunders TR, Pimsler M, Elfring DR. In-depth disinfection of acrylic resins. J Prosthet Dent. 1995;74(3):309-13.
21. Montagner $H$, Montagner $F$, Braun KO, Peres PE, Gomes BP. In vitro antifungal action of different substances over microwavedcured acrylic resins. J Appl Oral Sci. 2009;17(5):432-5. doi: 10.1590/S1678-77572009000500015

22. Requa-Clark B. Denture cleansers: council on dental materials, instruments, and equipament. J Am Dent Assoc. 1983;106(1):77-9.

23. Nascimento MS, Silva N, Catanozi MP, Silva KC. Effects of different disinfection treatment on the natural microbiota of lettuce. J Food Prot. 2003:66(9):1697-700.

24. Makino $\mathrm{S}$, Cheun $\mathrm{H}$, Tabuchi $\mathrm{H}$, Shirahata $\mathrm{T}$. Antibacterial activity of chaff vinegar and practical application. J Vet Med Sci. 2000;62(8):893-5. doi: 10.1292/jvms.62.893

25. Pinto $\mathrm{TM}$, Neves $\mathrm{AC}$, Leão $\mathrm{MV}$, Jorge $\mathrm{AO}$. Vinegar as an antimicrobial agent for control of Candida spp. in complete denture wearers. J Appl Oral Sci. 2008;16(6):385-90. doi: 10.1590/S1678-77572008000600006

26. Vijayakumar C, Wolf-hall CE. Evaluation of household sanitizers for reducing levels of Escherichia coli on iceberg lettuce. J Food Prot. 2002;65(10):1646-50

Received on: 22/2/2015 Final version resubmitted on: 17/3/2015 Approved on: 27/4/2015 
